\title{
Jezični slojevi i struktura međimurske hidronimije
}

\author{
DUNJA BROZOVIĆ RONČEVIĆ
}

Sveučilište u Zadru, F. Tuđmana 24i, HR - 23000 Zadar,

dbrozovic@unizd.hr

INES VIRČ

Institut za hrvatski jezik i jezikoslovlje, Ulica Republike Austrije 16, HR-10000 Zagreb,inovak@ihjj.hr

\begin{abstract}
SCN VIII/2 [2015], 5-19
Prispevek temelji na analizi dosedanjih dognanj na področju medžimurske hidronimije in na lastnih terenskih raziskavah, katerih cilji so bili sistematično zbiranje, obdelava in razvrščanje gradiva s področja hidronimije v Medžimurju. Klasifikacija hidronimov je izdelana na podlagi motivacijskih in tvorbenih vzorcev, posebna pozornost pa je posvečena razvrstitvi vodnih imen glede na njihovo jezikovno ozadje. V prispevku ni zajeta celotna medžimurska hidronimija, temveč so obravnavana najpomembnejša vodna imena vseh hidronimskih kategorij - imena pomembnih ali z jezikoslovnega vidika najzanimivejših rek, potokov, izvirov, jezer, ribnikov, mlak in barij.
\end{abstract}

The paper examines and describes the hydronymy of Međimurje, the far northern region of Croatia. Field research aimed at the systematic gathering, analysis and classification of names of bodies of water throughout Međimurje. The classification of hydronyms is based on motivational and word formational criteria, and special attention is paid to the classification of hydronyms according to their language of origin. While a complete account of all Međimurje hydronyms is beyond the scope of this paper, the analysis presented here considers the major rivers, streams and lakes, as well as those swamps, springs, ponds and wells whose names are particularly interesting from a linguistic point of view.

Ključne besede: Medžimurje, hidronimija, strukturna analiza, motivacijska analiza

Key words: Međimurje, hidronymy, structural analysis, semantic analysis 


\section{Uvod}

Hidronimima nazivamo vlastita imena vodnih objekata, a onomastička disciplina koja se bavi znanstvenim proučavanjem hidronimije naziva se hidronomastika. Iako su s jezičnopovijesnoga gledišta osobito zanimljiva imena većih vodenih tokova jer rjeđe od ostalih onima podliježu promjenama, hidronomastika ne proučava samo imena tekućica, dakle rijeka i potoka, ${ }^{1}$ već i imena svih vodnih objekata, dakle i imena vrelišta, močvarišta, jezera i mora. Postojanost imena većih rijeka vezana je uz njihovu trajnost i relativnu nepomičnost te se stoga ta imena nasljeđuju i prenose s demografskim promjenama, odnosno rijetko podliježu preimenovanjima uvjetovanim etnojezičnim, povijesnim ili političkim previranjima te stoga predstavljaju iznimno dragocjena svjedočanstva za proučavanje povijesti naroda i jezika na prostoru njihova nastanka.

Vodni su tokovi kroz povijest obično bili prirodnim granicama pojedinih entiteta, pa su tako i današnje hrvatske granice većim dijelom određene rijekama, odnosno Jadranskim morem na jugu. Sjeverna hrvatska granica s Mađarskom najvećim dijelom leži uz tokove Mure i Drave, istočna uglavnom prati Dunav, zapadna je granica sa Slovenijom dijelom omeđena Dragonjom, Kupom i Sutlom, a uz granicu s Bosnom i Hercegovinom teku Sava i dijelom Una. Poput Hrvatske i najsjevernija je hrvatska županija, Međimurje, sa svih strana okružena vodama. Od sjevera i sjeverozapada omeđuje je rijeka Mura, a s juga rijeka Drava. ${ }^{2}$ Zapadna se granica, prema Sloveniji, pretežito može povući uz potok Trnavu, na sjever uz potok Šantavec, a dalje se proteže sjeveroistočno od Robadja te južno od Gibine dolazi do Mure. Zbog hidrološkoga je bogatstva ovo područje osobito pogodno za provođenje hidronomastičkih istraživanja.

\section{Zemljopisni položaj i naselja u Međimurju}

Međimurje nije samo najsjevernija hrvatska prirodno-geografska regija, već i jedinstvena političko-administrativna jedinica, županija smještena na otprilike $730 \mathrm{~km}^{2}$ površine. U tri međimurska grada (Čakovec, Prelog i Mursko Središće) i 22 općine živi oko 120000 stanovnika, a grad Čakovec ujedno je i upravno i političko središte Međimurske županije.

Prirodno-geografski, Međimurje je smješteno na dodiru dviju velikih europskih reljefnih cjelina - istočnih Alpa i Panonske nizine, na temelju čega se diferenciraju dvije osnovne morfološke cjeline: brežuljkasto gornje (prevladava

${ }^{1} \mathrm{U}$ onomastičkoj se terminologiji ta imenska skupina naziva potamonimima.

${ }^{2}$ Današnja međimurska granica ne slijedi posvema tokove Mure i Drave, tj. međimurski se dio nalazi i s onu stranu obiju rijeka. 
blago valovit, raščlanjen reljef) i nizinsko donje Međimurje (naplavna ravnica uz Dravu i Muru). ${ }^{3}$ Najviši vrh je Cimermanov brijeg, visine 345,03 metara. ${ }^{4}$

Po hidrogeološkim kriterijima područje Međimurja može se podijeliti u četiri cjeline koje se poklapaju s morfološkom i geološkom građom terena:

1) područje zapadnoga dijela Međimurja ${ }^{5}$

2) čakovečki praporni ravnjak ${ }^{6}$

3) područje Dravske nizine ${ }^{7}$

4) područje Murske nizine. ${ }^{8}$

Čitavo je Međimurje veoma bogato vodama. Slivovi Mure i Drave, dviju velikih rijeka koje ga omeđuju, područja su snažnih erozijskih procesa, koji su uz obilježja samoga tla (u hidrografiji nazivanima automorfnim i hidromorfnim), ${ }^{9}$ utjecali na pojavu niza blatišta, vrelišta, jezera, mlaka, ribnjaka i potoka na području Međimurja.

\section{Povijesni kontekst međimurske toponimije}

Toponimi su općenito, a osobito hidronimi, pouzdani svjedoci povijesti etničkih zajednica i jezika unutar kojih su nastali. Pritom su često upravo imena rijeka i naselja nastalih na njihovim obalama, uz neka osobna imena, zabilježena u najstarijim zapisima, i jedini su očuvani svjedoci pojedinih iščezlih jezika. Prostor Međimurja, osobito područje porječja rijeke Mure još je u prapovijesno doba imalo važan geostrateški položaj, osobito s obzirom na činjenicu da je tim pravcem prolazio ogranak jantarskoga puta. Od etničkih skupina koje su živjele na prostoru Međimurja, treba izdvojiti Panonce (Pannonii) koji su barem djelomice na tom prostoru obitavali u suživotu s Keltima. ${ }^{10}$ Nakon rimskih

${ }^{3}$ Granica između ta dva dijela poklapa se s izohipsom od 200 metara nadmorske visine.

${ }^{4}$ Vidi: http://www.mnovine.hr/vijesti/medjimurje/drustvo/foto:-istrazivanja-potvrdila--mohokos-nije-najvisi-vrh-medimurja i http://www.vecernji.hr/hrvatska/otkrice-medimurje-naraslo-metar-i-pol-984609.

${ }^{5} \mathrm{U}$ tom su području od hidrogeoloških pojava registrirani kopani zdenci i vrela.

${ }^{6}$ Uz jugoistočni se rub javlja više izvora veoma male izdašnosti.

${ }^{7} \mathrm{~S}$ hidrološkoga je gledišta Dravska nizina najznačajnija.

${ }^{8}$ Manje izvore cijednoga karaktera nalazimo tamo gdje je površinski trošni pokrivač deblji. Dubokim istražnim bušotinama za naftu utvrđene su i pojave termalne vode (iznad $150^{\circ} \mathrm{C}$ ).

${ }^{9}$ Automorfna tla zauzimaju povišene i ocijeđene položaje. Ova tla nemaju dodatnog vlaženja poplavnim vodama, niti podzemne vode ulaze u aktivni dio profila. Na razvoj hidromorfnih tla utječu oborinske, poplavne i podzemne vode (Hrvatske vode 1998: 5).

${ }^{10} \mathrm{U}$ literaturi se sreću različita mišljenja o tome koje je panonsko pleme nastanjivalo Međimurje: »Vrlo su važne vijesti o etničkim skupinama na ovom prostoru. Grčki geograf Strabon (65. god. prije Krista - 24. god. po Kristu) u svom djelu "Geografija" spominje rijeku Dravu (Drabos) i plemena Panona. U "Monumentum Ancyranum" - svojem političkom testamentu rimski car Tiberije Ističe: "Plemena Panona, koje prije mojeg 
osvajanja početkom 1. st. n. e., Rimljani u doba cara Tiberija osvojena područja organiziraju u provinciju Ilirik te se prostor današnjega Međimurja nalazio $u$ rimskoj provinciji Panoniji. U antičko je doba na tom području utemeljeno više naselja kojima se imenski kontinuitet nije održao. Mađari u Panonsku nizinu provaljuju krajem IX. stoljeća, a potpisivanjem sporazuma s ugarskim kraljem Kolomanom 1102. godine, uspostavlja se personalna unija Hrvatske i Ugarske. Neprestano svojatanje Međimurja od strane Mađara, višekratno odcjepljenje od Hrvatske i ponovno ulaženje u njezin sastav, osnovna su karakteristika političkih previranja tijekom idućih stoljeća. Godine 1861. Međimurje je opet pripojeno Ugarskoj te je $\mathrm{u}$ to doba mađarski kao službeni jezik uveden u sudstvo, školstvo, crkvu, vojsku. Uslijedila je sustavna mađarizacija imena svih međimurskih naselja (1896.), ${ }^{11}$ a mađarskim riječima iskvarena međimurska kajkavština proglašena je »međimurskim jezikom« na kojem od 18. svibnja 1884. izlazi i list Muraköz - Medjimurje (Kalšan 2006: 230-237). Tijekom Prvoga svjetskog rata Međimurje je pripadalo Ugarskom Kraljevstvu koje je bilo sastavnim dijelom Austro-Ugarske Monarhije, a tek je prema odluci Versajskoga mirovnog ugovora iz 1920. Međimurje pripalo Kraljevini Srba, Hrvata i Slovenaca, kasnije Kraljevini Jugoslaviji. Početkom Drugoga svjetskog rata njemačka je vojska okupirala Međimurje, a nakon što je 16. travnja 1941. u Međimurje ušla mađarska vojska te je ono proglašeno mađarskim okupacijskim područjem i priključeno mađarskoj županiji Zala, mađarska je vlast još jednom započela snažnu mađarizaciju u školstvu i upravi. U travnju 1945. Međimurje je oslobođeno i vraćeno pod upravu tadašnje DFJ, a od 1992. godine Međimurje je u upravno-teritorijalnom smislu samostalna županija.

\section{O hidronimiji Međimurja}

Starošću svojega podrijetla, arhaičnošću tvorbe i postojanošću likova, hidronimi, odnosno u prvom redu imena rijeka, izdvajaju se od ostalih imenskih kategorija i predstavljaju iznimno dragocjena svjedočanstva za proučavanje povijesti narodâ i njihovih jezika. Unatoč turbulentnoj povijesti ovoga područja, s izuzetkom imena velikih rijeka koje ga omeđuju, današnja međimurska

principata nikada rimska vojska nije posjetila, doveo sam, nakon njihova pokorenja od strane Tiberija Nerona, mojeg tadašnjeg pastorka i legata, pod vlast rimskog naroda i proširio sam granice sve do obala Dunava." Plinije Stariji (23. - 79. godine po Kristu) pak piše da tamo gdje teče rijeka Drava žive Serreti, Serapilli, Iasi i Andizeti. Prema klasičnom filologu A. Mayeru u Međimurju su živjela plemena Serapill, a njihovo ime govori da koriste "žitne jame". Serapilli su, prema tome, autohtono stanovništvo koje je pomiješano s Keltima dočekalo rimske osvajače« (Kalšan 2006: 14). Iako postoje neprijeporni dokazi o keltskome obitavanju na području današnjega Međimurja, kao i na mnogim hrvatskim prostorima, toponimijskih je prežitaka koji bi to potvrđivali veoma malo.

${ }^{11}$ Opširnije o procesima mađarizacije međimurskih ojkonima v. Frančić, Žagar Szentesi 2008: 59-80. 
hidronimija vjerno oslikava hrvatsko, odnosno slavensko podrijetlo najvećega broja u ovome radu obrađivanih imena.

Hidronimija Međimurja do sada nije podrobnije proučavana, ${ }^{12}$ a sustavnih terenskih istraživanja donedavno na tome prostoru gotovo da i nije bilo. ${ }^{13}$ Ovaj se rad temelji na vlastitim terenskim istraživanjima kojima je cilj bio prikupljanje i obradba hidronimijske građe u Međimurju, odnosno razredba hidronima prema motivacijskim i tvorbenim obrascima te prema njihovu jezičnom podrijetlu. Sustav hidronima ili hidronimiju Međimurja čine imena rijeka, potoka, vrela, jezera, ribnjaka, mlaka i blatišta.

Korpus za analizu u ovome radu čini 85 imena blatišta, 194 imena vrela, 14 imena jezera, 176 imena mlaka, 201 ime potoka i 68 imena ribnjaka, tj. 738 hidronima prikupljenih terenskim istraživanjem u Međimurju. Prikupljen i sistematizirani korpus hidronima može se slikovno prikazati prema zastupljenosti pojedinih hidronimijskih skupina u Međimurju:

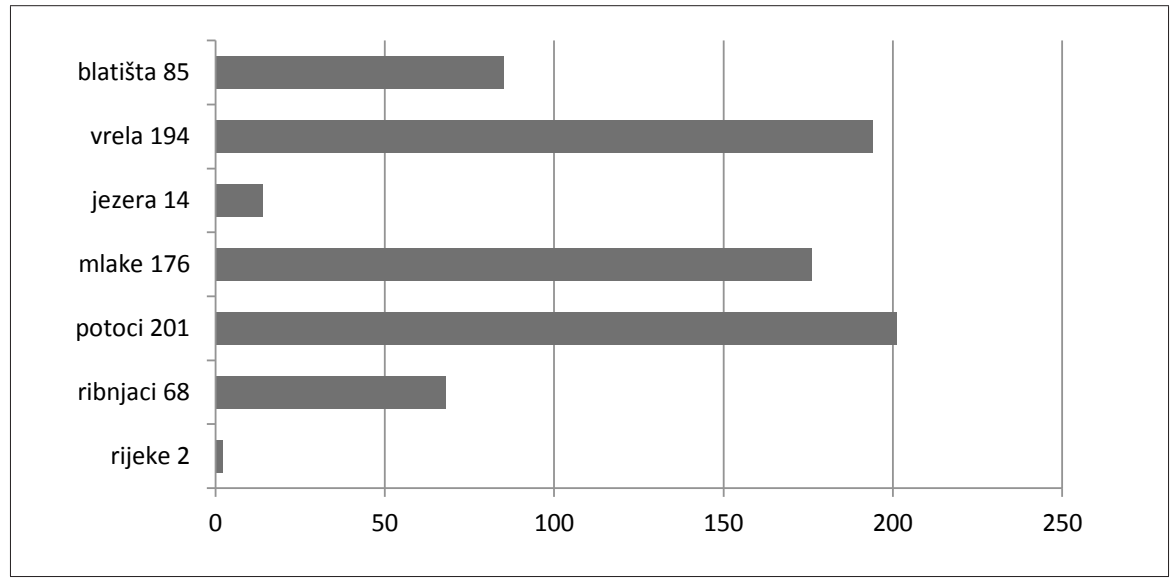

Slika 1: Zastupljenost hidronimijskih skupina u Međimurju

${ }^{12} \mathrm{O}$ međimurskoj su hidronimiji, u prvom redu o slivu Drave i Mure pisali I. Kalinski i M. Peti (1973.), rubno je se u svojim radovima o međimurskoj toponimiji dotiče A. Frančić te D. Brozović Rončević u svojim radovima o hrvatskome hidronimijskom sustavu. O pojedinim problemima relevantnim za hidronomastička istraživanja pisali su i: A. Bregović i suradnici, 2004: Život uz Dravu nekad i danas. Varaždin; S. Golub: Mura, slikovni vodič kroz zaštićeni murski krajolik. Čakovec; isti, 2004: Međimurje: elementarno i profinjeno. Čakovec; M. Purić Hranjec, 2005: Drava u Međimurju još uvijek živi. Čakovec.

${ }^{13}$ Sustavna je hidronomastička istraživanja u Međimurju provela Ines Virč u okviru rada na projektu Onomastička i etimologijska istraživanja hrvatskoga jezika (MZOS) koji je u Institutu za hrvatski jezik i jezikoslovlje vodila Dunja Brozović Rončević. Terensko je prikupljanje hidronimijske građe za ovaj rad obavljeno u skladu s Uputama za prikupljanje onomastičke građe institutskoga Odjela za onomastiku i etimologiju te je pod naslovom Hidronimija Međimurja Ines Virč obranila kvalifikacijski rad na doktorskom studiju Filozofskoga fakulteta Sveučilišta u Zagrebu 2009. godine. 
Iako su dvije rijeke koje omeđuju obrađivano područje, Mura i Drava, neprijeporno za Međimurje najvažnije u gospodarstvenom, pa i u političkom smislu, za hidronomastička su istraživanja jednako važni svi hidronimi. Iz priloženoga je prikaza razvidno da je u ukupnom hidronimijskom korpusu Međimurja najviše zabilježenih imena potoka (27 \%), potom slijede imena vrela $(26,3 \%)$, mlaka $(23,9 \%)$, blatišta $(11,5 \%)$, ribnjaka $(9,1 \%)$, jezera $(1,9 \%)$ i samo dva imena rijeka $(0,27 \%)$.

Svi toponimi, pa tako i hidronimi, tvoreni su postupkom onimizacije od riječi nekoga jezika, najčešće od apelativa. Ni u jednom toponomastičkom sustavu ne postoje primarna imena, iako je, što su imena starija, teže proniknuti u primarno značenje apelativa od kojih su nastala. Kako bi se izdvojili inojezični elementi u međimurskoj hidronimiji, potrebno je sustavno popisati i analizirati tvorbene elemente i modele tvorbe unutar jezika u kojem je ime nastalo, odnosno potrebno je provesti motivacijsko-tvorbenu i semantičku klasifikaciju prikupljenih hidronima. Inojezični se elementi mogu prepoznavati u osnovi ili tvorbenim elementima rabljenim pri postupku toponimizacije. Na rubnim prostorima etnojezičnih dodira česti su i slučajevi da se na slavensku osnovu dodaju inojezični sufiksi ili obratno, no iako je Međimurje prostor stoljetnoga suživota Hrvata i Mađara, takvih je imenskih tvorbi relativno malo u međimurskoj hidronimiji. Hidronimijski likovi, u ovom radu analiziranih imena, bilježe se u hrvatskoj dijalektologiji uobičajenim sustavom fonetske transkripcije za mjesne govore, odnosno dijalekt unutar kojega je pojedino ime zabilježeno.

\subsection{Tvorbena i strukturna analiza međimurskih hidronima}

S obzirom na strukturu hidronimi mogu biti jednorječni, dvorječni ili višerječni. ${ }^{14}$

A) Jednorječni hidronimi prema tvorbenom postupku razvrstavaju se u tri temeljne skupine:

1. hidronimi nastali onimizacijom apelativa bez ikakvih dopuna (npr. Kántoš (< kantoš 'vrsta ribe'), Opečjọo (< opečjọ̀k 'vrsta cigle; elementi na kalijevoj peći'), Repúx (< repuh).

2. hidronimi nastali dodavanjem afikasa:

a. hidronimi sufiksalne tvorbe (npr. Bistrẹc, Empesk, Lüžjęk)

b. hidronimi prefiksalne tvorbe (npr. Zápolé)

c. hidronimi prefiksalno-sufiksalne tvorbe (npr. Pádolẹk).

3. hidronimijske sraslice (npr. Senókọ̌a, Vódopad).

${ }^{14}$ Primjeri koje donosimo samo oprimjeruju pojedine tvorbene obrasce. 
Najzastupljeniji sufiksi u tvorbi jednorječnih međimurskih hidronima mogu se tablično prikazati:

Tablica 1: Sufiksalna tvorba međimurskih hidronima

\begin{tabular}{|c|c|c|c|c|c|c|c|}
\hline \multicolumn{8}{|c|}{ Sufiksalna tvorba međimurskih hidronima } \\
\hline Sufiks & $\varnothing$ & $-e c c$ & $-i c a$ & $-e ̧ k$ & $\check{s} \check{c} a k / s ̌ c ̌ c e s$ & $-j e$ & $-o k$ \\
\hline Ukupno & 188 & 36 & 27 & 16 & 14 & 5 & 5 \\
\hline
\end{tabular}

B) Analizom dvorječnih međimurskih hidronima može se izdvojiti devet modela (npr. Xidrocentrála Čàkovẹc; Šódẹr grába; Màlo Žerjaviščes; Bukóvska kopája; Stọra Trščánska; Nòva Múra; Birovova grába; Prẹ Xómpo; Tóto móres).

Analiza dvorječnih međimurskih hidronima može se slikovno prikazati:

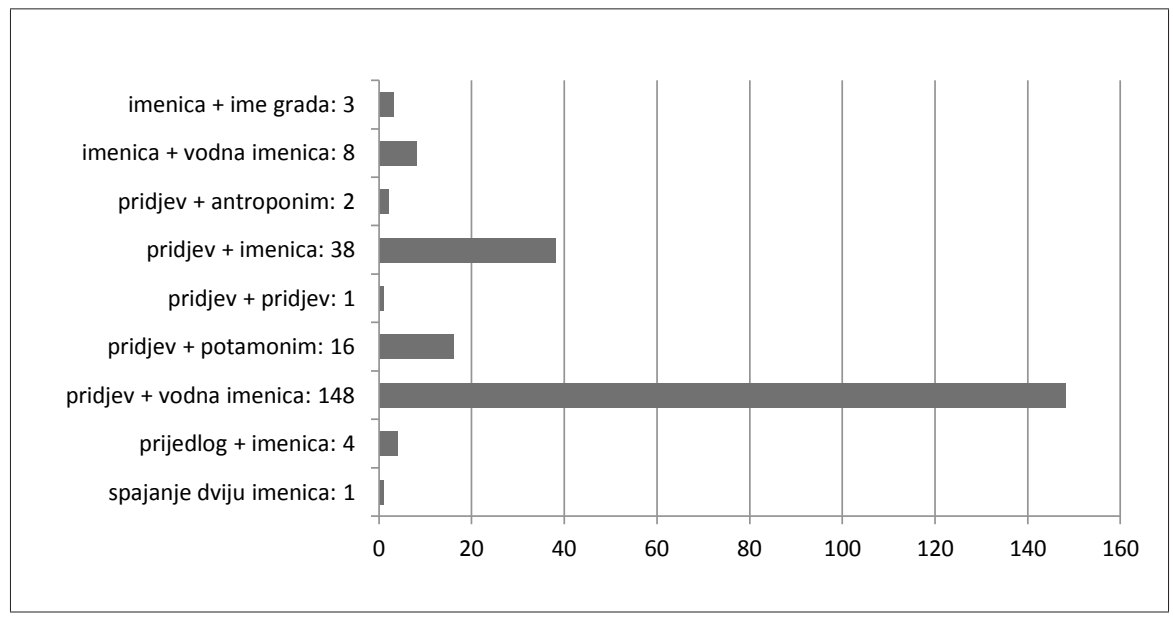

Slika 2: Strukturna analiza dvorječnih međimurskih hidronima

Usporedbom modela kod dvorječnih međimurskih hidronima zapaža se da je najčešći model pridjev + vodna imenica (67 \%), što u brojkama uglavnom odgovara postotku zabilježenom u drugim dijelovima Hrvatske.

C) Analizom višerječnih međimurskih hidronima može se izdvojiti sedam modela koji se mogu oprimjeriti imenima: Stộri rukọvị Drọvę; Zvirálna pod Bájzękom; Mlàka na Cúrko; Mlàka na kŕčo; İvor pod Rimščakom; Izvor nâ Móškaj sinókošaj; İzvor na Mr̉kvị i slikovno prikazati: 


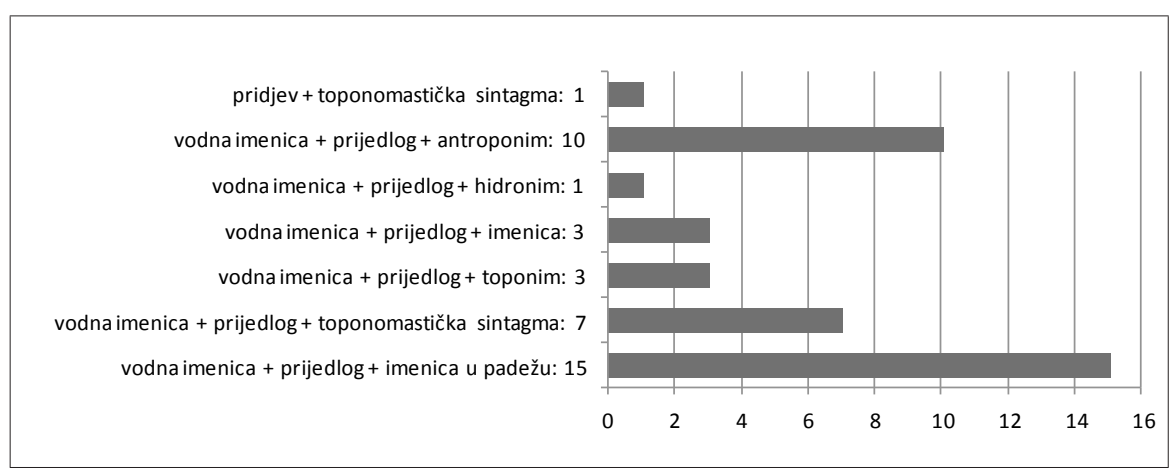

Slika 3: Strukturna analiza višerječnih međimurskih hidronima

Usporedbom udjela broja višerječnih međimurskih hidronima zapaža se da je najčešći model vodna imenica + prijedlog + imenica u padežu $(37,5 \%)$.

Složenost pojedinih hidronimnih likova često je obrnuto proporcionalna poznatosti i važnosti pojedinoga vodnog objekta na koji se ime odnosi, odnosno brojem ljudi kojima je pojedino ime prepoznatljivo i njime se služe. Stoga nas i površan pogled na gore prikazane tablice odnosno grafikone upućuje na zaključak da se među međimurskim hidronimima brojčano izdvajaju jednočlane tvorbe izvedene izravnom toponimizacijom apelativa i da su među dvočlanim hidronimima najzastupljenije tvorbe od pridjeva i vodne imenice, dok je broj višečlanih hidronima veoma ograničen.

\subsection{Motivacijska klasifikacija međimurskih hidronima prema semantizmu osnove}

S obzirom na izvorno značenje osnove, odnosno leksema od kojega je ime tvoreno, hidronimi se mogu razvrstati u devet temeljnih skupina, za koje većinom nalazimo potvrde i među međimurskim hidronimima:

1. hidronimi motivirani geomorfološkim odlikama zemljopisnoga objekta (npr. struga 'korito rijeke ili potoka; udubljeno mjesto u koritu rijeke; dno rijeke' (Strúga), vusekje 'usjek' (Vusékjẹ (BRE)), zaton 'zaljev; uvala; ravno mjesto na vodi, luka; riječna livada' (Zọton).

2. zemljopisna imena od drugih toponima - hidronimi nastali od starijih toponima i nalaze se u njihovoj okolici; većinom dvočlana imena, čiji su pridjevi nastali od drugoga, važnijeg toponima, a identifikacijski je član obično zemljopisni pojam (npr. Vugrišinẹc, Žọ́bnịk).

3. hidronimi motivirani nazivima bilja, biljnoga pokrova i biljnih zajednica (npr. gubač 'gubač ‘šišarica' (Gúbač), jales < jalša ‘joha' (Jáless), voljọ́k 'vrsta trave' (Vọlók).

4. hidronimi izvedeni od naziva životinja (npr. xobọd 'obad' (Xọộd), ribjak 'ribnjak' (Ribjak), žužika 'raca' (Žǔžịčka)). 
5. hidronimi motivirani ljudskom djelatnošću (npr. čiga 'vitlo, kolotur; motka, opterećena na jednom kraju, za vađenje vode iz zdenca' (Č́'ga), ograda 'ograda' (Ógrada), Stọ́rị mệlịn (MS).

6. hidronimi motivirani prirodnim pojavama (nisu zabilježeni).

7. hidronimi antroponimijskoga postanja (npr. Fŕjoy ( $<$ Frjoy $<$ Frajo 'Franjo'), Karlòt $(<$ Karlo), Margética ( $<$ Margetica $<$ Margeta $<$ Margareta)).

8. hidronimi etnonimskoga (ili etničkoga) postanja (nisu zabilježeni)

9. hidronimi nejasna postanja ili nejasne motiviranosti (npr. Hìkelịca, Madenšč́a).

Klasifikacija međimurskih hidronima po semantičkim skupinama može se slikovno prikazati:

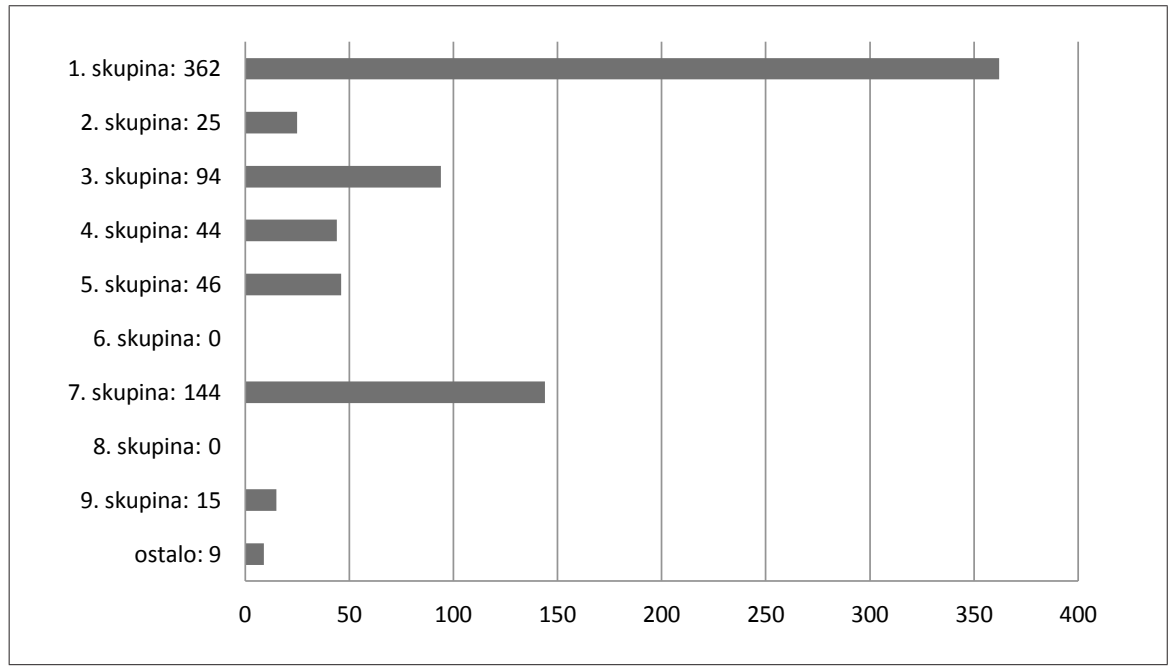

Slika 4: Semantička klasifikacija međimurskih hidronima

Usporedbom udjela međimurskih hidronima po skupinama, zapaža se da ih je najviše motivirano geomorfološkim odlikama zemljopisnoga objekta $(48,85 \%)$, što se poklapa sa situacijom na čitavom hrvatskom području. ${ }^{15}$ Hidronimi motivirani prirodnim pojavama, kao i hidronimi etnonimskoga (ili etničkoga) postanja, u Međimurju nisu zabilježeni.

Posebno su zanimljive hidronomastičke metafore, među kojima je najbrojnija skupina hidronima koji svoj odslik nalaze u predmetima materijalne kulture

15 „Statistička obradba hrvatskoga zemljopisnog nazivlja pokazuje da gotovo $80 \%$ topografskih apelativa ima toponimijskih odraza, a oko $50 \%$ hrvatskih toponima u svojem imenu ima zemljopisni termin, što je znatno veći postotak nego u drugim slavenskim jezicima, a uvjetovan je iznimno razvedenom i raznolikom konfiguracijom tla na području Hrvatske. Onimizacija apelativa najčešća je naravno u mikrotoponimiji zbog semantičke jednoznačnosti pojedinih termina, čija se značenja precizno vezuju i poistovjećuju s osobinama i odlikama objekta na koji se odnose« (Brozović Rončević 2003: 3). 
(npr. grejęẹnka 'posudica u kojoj se zadržava toplina kuhana ili pečena jela' (Grejệnka (TU)), pinka 'vrsta kruha' (Pinkava (Ž)), ràtišče 'kosište, držalo kose' (Rátiščak (KU)).

Hidronimi nejasna postanja ili nejasne motiviranosti čine $2 \%$ građe.

\subsection{Hidronimija Međimurja prema podatcima Hrvatskih voda}

U slivu rijeke Mure registrirano je jedanaest bujičnih slivova (Dragoslavec, Goričica, Pleškovec, Jalšovec, Jurovčak, Gradiščak, Koncovčak, Gornji potok, Donji potok, Brodec, Jalšovnica), a u slivu rijeke Drave tri (Trnava (brdski dio), Zelena, Zejza).

Kao glavni vodotokovi Međimurja navode se Drava i Mura, a iza njih, najveća tekućica u Međimurju je Trnava. Prije izvođenja melioracijskih radova, s lijeve joj je strane pritjecao potok Goričica (danas Lateralni kanal ili Lateralac), a u donjem toku Bošćak, Korenica (danas kanal Muršćak) i Kopanec. Danas Trnava utječe u Muru kod Goričana, a ostali dio nekadašnje Trnave do ušća u Dravu dobio je ime Bistrec.

Problem velikih voda ${ }^{16}$ riješen je izgradnjom retencija ${ }^{17}$ i kanala. ${ }^{18}$

U slivu Mure izgrađena je retencija Selnica. Sliv Trnava ima pet retencija: Dragoslavec, Šenkovec, Globetka, Jegerseg i Pribislavec.

Kanal je prokop za navodnjavanje ili otjecanje. Prema podatcima Hidrotehnike d. o. o. Čakovec, u Međimurju postoji 161 kanal. Od 161 naziva kanala, na terenu je potvrđeno $14,29 \%$.

Najviše je kanala u čijoj se osnovi nalazi ime sela $(28,57$ \%), npr. Belica, Bogdanovec, Brezje. Po zastupljenosti, slijede kanali u čijoj se osnovi nalazi naziv bilja (Bakuc, Đerdov, Jagodnjaci), imena kanala koja se odnose na oblik, svojstva i izgled tla/vode (Brodec, Duge Njive, Krčevine), imena kanala koja se odnose na sastav i osobitosti tla (Berek, Cret i ogranak, Peski + Peski I), imena kanala, tj. simboli (npr. $K-10, K-11, K-13$ ), imena kanala koja su određena položajem (npr. Donji potok + produžetak, Gornji potok, Zaobalje), imena kanala antroponimijskoga postanja (npr. Hercegovica, Herjavec, Hrebec), imena kanala u čijoj se osnovi nalazi naziv životinja (npr. Hrušćica, Kozajc I + ogranci I - II, Pijavišće), imena kanala motivirana ljudskom djelatnošću (npr.

\footnotetext{
16 »Općenito se, prema UNESCO-vu i WMO-vu rječniku hidroloških pojmova (1992.) velika voda može definirati na tri načina: 1 . kao povišenje - obično naglo - vode $u$ vodotoku do najviše vrijednosti, od koje razina vode počinje polagano opadati, 2. kao veliki tok vode mjeren visinom vodostaja ili veličinom protoka, 3. kao rastuća plima« (Žugaj 2004: 2).

17 »Retencije su povremene jednonamjenske akumulacije za suzbijanje velikih voda na nizvodnom području. Suzbijanje se postiže privremenim zadržavanjem dijela velikih voda u retencijskom prostoru i reguliranim ispuštanjem kroz evakuacijske organe« (Hrvatske vode 1998a: 14).

${ }^{18}$ Kanal je prokop za navodnjavanje ili otjecanje.
} 
Pruga, Vahte I - III, Zdenci), hidronimijske metafore (npr. Gačice, Kerača ${ }^{19} i$ ogranak, Potkova) te imena kanala u odnosu prema drugim hidronimima (npr. Krke I-VI, Murščak).

$\mathrm{U}$ Hrvatskim vodama ne postoje »detaljniji podatci $\aleph^{20} \mathrm{o}$ izvorima vode na području Međimurja, iako se na nekoliko mjesta ističe da u brdskom dijelu postoji manji broj registriranih izvora (41) male izdašnosti.

Podatci o ribolovnim vodama, tj. o ribnjacima na području Međimurja, dostupni su u SŠRD-u Međimurske županije ${ }^{21}$ ili na http://www.ssrd.hr/ribolovna-mjesta/.

\subsection{Jezični slojevi u međimurskoj hidronimiji ${ }^{22}$}

Poznata je činjenica da imena većih rijeka pripadaju najstarijem jezičnom supstratu, dok tzv. mikrohidronimija uglavnom odražava mlađe jezične slojeve i podložnija je promjenama.

Supstratna imena velikih rijeka na području Hrvatske uglavnom pripadaju najstarijem imenskom sloju koji se u onomastičkoj literaturi obilježava nazivom »staroeuropska hidronimija«. U osnovi se toga hidronimijskoga sloja gotovo uvijek može izdvojiti neki indoeuropski korijen kojim se označuje protjecanje ili pojedino svojstvo same vode. Ime rijeke Drave, desnoga pritoka Dunava, koja izvire u južnom Tirolu te većim dijelom čini južnu granicu Međimurske županije, ${ }^{23}$ pripada tomu najstarijem hidronimijskom sloju. U antičkim se povijesnim vrelima njezino ime bilježi likovima Draus (Plinije III, 147)

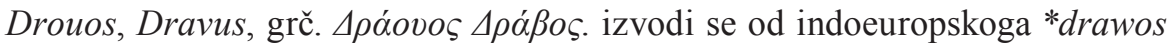
'tijek, tok' od korijena *drew- s pretpostavljenim značenjem 'teče, trči' (usp. skt. dravah 'tok, rijeka', dravati 'teći'), od kojega se na europskom prostoru izvodi još nekoliko hidronima (Drawe u Njemačkoj, Dravinè u Litvi, Drawen u Britaniji i dr.). Ime druge važne međimurske rijeke Mure, lijevoga pritoka Drave koja izvire u niskim Tatrama, a većim dijelom se poklapa sa sjevernom granicom Međimurja odnosno Republike Hrvatske prema Mađarskoj, također je relativno rano potvrđeno u povijesnim vrelima kao Marua, Muora, Muer itd. Ipak, njezino se ime ne može tako pouzdano, kao ime rijeke Drave, pripisati najstarijem hidronimijskom sloju. ${ }^{24}$ Prema nekim se istraživačima ime tvori od

${ }^{19}$ Kerača je drveni štap.

${ }^{20}$ Pod »detaljnijim podatcima« mislimo na imena vrela.

${ }^{21}$ Adresa SŠRD-a Međimurske županije jest: A. Schulteissa 19, Čakovec.

${ }^{22}$ Pregled jezičnih slojeva u međimurskoj hidronimiji napravljen je prema Brozović Rončević 1997: 339-368.

${ }^{23}$ Od ukupne njezine dužine od preko 700 km, rijeka Drava kroz Hrvatsku protječe dužinom od oko $300 \mathrm{~km}$.

${ }^{24}$ A. Mayer smatrao je da se ime rijeke Mure možda može iščitavati u jednoj antičkoj potvrdi za rijeku Ira ([M]ura) u Panoniji koju navodi Anon. Ravenjanin, ali je i to povezivanje neuvjerljivo (Mayer 1957: 174). 
ie. hidronimske osnove *mar- od čega je antičko ime Marus, ali povezivanje s današnjim imenom Mura nije uvjerljivo, kao ni povezivanje s hidronimima Morava. ${ }^{25}$ Javlja se i tumačenje da današnji vokalizam možda odražava germanski utjecaj, dok se antički čuva u slovenskom imenu Međimorje (Međimurje) za 'prostor među vodama', tj. 'između Mure i Drave'. Zanimljivo je da se hidronim Mura bilježi i u Poljicama te je možda ipak riječ o slavenskoj, a ne supstratnoj tvorbi. M. Snoj također pretpostavlja slavensko podrijetlo imena rijeke Mure te na temelju i slovenskoga dijalektnog leksika njezino ime izvodi od prasl. pridjeva *murs 'taman', pa bi Mura označavala 'tamnu ili crnu vodu' odnosno rijeku što je veoma česta motivacija u hidronimiji. ${ }^{26}$

Već smo istaknuli da daleko najbrojniji sloj međimurskih hidronima čine imena hrvatskoga, odnosno slavenskoga podrijetla, tvorbeno i motivacijski uglavnom podudarna hidronimskim likovima zabilježenim na drugim hrvatskim prostorima bogatim vodom. Adstratni hidronimijski sloj koji čine imena nastala u dodiru Hrvata s neslavenskim jezicima i narodima, veoma je slabo zastupljen na području Međimurja.

Od inojezičnih elemenata koje prepoznajemo u međimurskoj hidronimiji najprisutniji je germanski, odnosno njemački jezični sloj, a potom očekivano slijedi mađarski. Međutim, s obzirom na to da je uglavnom riječ o manjim, ili manje značajnim vodnim objektima, ponekad je teško razlučiti je li kod pojedinih imena dovršen proces toponimizacije ili stanovništvo za identifikaciju tih objekata samo rabi apelative germanskoga, odnosno mađarskoga podrijetla. U mikrohidronimiji je granicu između apelativa i hidronima često veoma teško razlučiti. U svakom slučaju, od toponomastičkih imenica koje pripadaju germanskomu sloju, ${ }^{27}$ a rubno se odražavaju u međimurskoj toponimiji izdvajamo: bäjer 'bara, jezero' < njem. Weiher 'malo jezero, ribnjak', gmajna 'pašnjak' $<$ njem. gemeine 'opći, zajednički', graba < germ. graba, grunt 'zemljište, imanje', šanac/šanc 'jarak, graba, jarak oko vojničkog tabora' < njem. Schanze.

Iako je u povijesti Međimurje višekratno bilo pod ugarskom upravom, a sjeverna je međimurska granica neprijeporno područje stoljetnih jezičnih dodira, mađarski je sloj u međimurskoj hidronimiji gotovo zanemariv. Nešto je zastupljeniji u drugim toponimnim skupinama, osobito u mikrotoponimiji rubnih područja, primjerice Fizeš kao ime vrbika, ali uglavnom je riječ o toponimima tvorenim u hrvatskoj jezičnoj zajednici od hungarizama koji su u pojedinim mjesnim govorima već postali dijelom općega leksika. Izdvojiti se

${ }^{25}$ Važno je spomenuti da hidronim Murava bilježimo i na otoku Braču, ali taj, kao i mnoge srodne toponime treba izvoditi od naziva za 'mekanu, mladu travu'.

${ }^{26}$ Za podrobnije tumačenje imena rijeke Mure koja je i slovenska rijeka, vidi Snoj 2009: 275.

27 »Germanske su posuđenice u zemljopisnoj terminologiji vrlo rijetke, osobito u usporedbi s mnogobrojnim riječima koje su iz njemačkoga ušle u kulturni leksik hrvatskoga, osobito na sjeveru i sjeverozapadu na kolokvijalnoj razini« (Brozović Rončević 2003: 11). 
mogu hidronimi tvoreni od apelativa mađarskoga podrijetla: ${ }^{28}$ Veliki Berek $<$ bereg 'močvara' < mađ. berek, mezova 'oranica, polje' < mađ. mező 'polje', siget $<$ mađ. sziget 'otok', vizivode 'voda' < mađ. viz.

Očekivano, u međimurskoj hidronimiji ne nalazimo imena turskoga podrijetla, osim apelativa đol 'jezero, kaljuža' < tur. göl 'jezero' koji je također prihvaćen mađarskim posredništvom.

\section{Zaključak}

Međimurska je županija bogata vodama, kako podzemnim i površinskim na svojem prostoru, tako i vodama koje prolaze rubnim dijelovima Međimurja, tj. granicom. Imena voda u području Drave i Mure donekle su istražena, ali je poznavanje međimurske mikrohidronimije znatno skromnije.

Međimurje je jedan od hidronomastički najzanimljivijih terena zbog svoje reljefne raznolikosti, specifičnoga položaja na granici sa Slovenijom i Mađarskom, prožimanja različitih jezičnih sustava te zbog hidrološkoga bogatstva.

S obzirom na povijesna zbivanja i zemljopisni položaj Međimurja, u međimurskim su hidronimima uz idioglotske pretkazivi i leksemi aloglotskoga postanja. Dakle, osim što su hidronimi pokazatelji povijesnih mijena i gospodarskih kretanja, nose i jezično relevantne obavijesti.

Nažalost, mnogobrojni su hidronimi zauvijek zaboravljeni, a nekoliko ovdje analiziranih, više ni ne postoji. Blatišta postaju smetlišta, putovi do izvora neprohodni, jezera se pretvaraju u šljunčare, mlake se zatrpavaju, samo još pokoje dvorište krasi ribnjak, potoci postaju kanali, a njihova se imena u službenim popisima sve češće označuju brojevima. Ako su imena svjedoci naše prošlosti i zalog naše jezične budućnosti, zadaća je ovoga rada bila da se ta imena prikupe i klasificiraju kako bi se i u budućnosti mogla jezično analizirati, i onda kada vodnih objekata na koje se ona odnose više i ne bude.

\section{LITERATURA}

Zdenko BALOG, 2009: Srednjovjekovni toponimi sjeverne Hrvatske - kulturološki i interdisciplinarni aspekti toponomastike. Podravina VIII/15, 74-101.

Zvonimir BARTOLIĆ, 1996: Toponim Međimurje. Hrvatski sjever 2-3, 49-71.

Franc BEZLAJ, 1956: Slovenska vodna imena. I del (A-L). Ljubljana: SAZU.

--, 1961: Slovenska vodna imena. II del (M-Ž). Ljubljana: SAZU.

${ }^{28}$ Prikaz utjecaja mađarskoga jezika na hrvatsku hidronimiju dao je Dickenmann 1966. u drugom dijelu svoje monografije o hidronimiji slijeva Save, gdje kao dodatak donosi i popis mađarskih hidronima. 
Dunja BROZOVIĆ RONČEVIĆ, 1995: Staroeuropska hidronimija. Filologija 24-25, 81-86.

- -, 1996: O sinonimnim indoeuropskim korijenima u hidronimiji. Suvremena lingvistika 41-42, 95-101.

- -, 1997: Hidronimi s motivom vrelišta na povijesnom hrvatskom jezičnom području. Folia onomastica Croatica 6, 1-40.

- -, 1999: Nazivi za blatišta i njihovi toponimijski odrazi u hrvatskom jeziku. Folia onomastica Croatica 8, 1-44.

- -, 2003: Inojezični elementi u hrvatskome zemljopisnom nazivlju. Hrvatski dijalektološki zbornik 12, 3-14.

- -, 2010: Toponomastičko nazivlje između imenoslovlja i geografije. Folia onomastica Croatica 19, 37-46.

Ernst DICKENMANN, 1966: Studien zur Hydronymie des Savesystems. Band I-II. Heidelberg.

Petar FELETAR, 2005: Istočno Međimurje. Samobor: Meridijani.

Anđela FRANČIĆ, 2000: Prvi spomen Međimurja. Kaj 1-2, 61-70.

Anđela FRANČIĆ; Orsolya ŽAGAR SZENESI, 2008: Međimurska ojkonimija na mađarski način. Folia onomastica Croatica 17, 59-80.

László HADROVICS, 1934: Muraköz helynevei. Budapest.

Ivo KALINSKI, 1973: O istraživanju hidronimije dravskoga sliva I. Filologija 7, 101-111.

Ivo KALINSKI; Mirko PETI, 1973: O istraživanju hidronimije dravskoga sliva II. Filologija 7, 113-124.

Vladimir KALŠAN, 2006: Međimurska povijest. Čakovec.

Anton MAYER, 1957: Die Sprache der alten Illyrier. Wien.

Stjepan SEKEREŠ, 1970: Slavonska vodna imena. Zbornik za filologiju i lingvistiku 17, 175-196.

Marko SNOJ, 2009: Etimološki slovar slovenskih zemljepisnih imen. Ljubljana: Založba ZRC.

Rudolf SUPPAN, 1984: Unsere Mur Fluss im grünen Land. Graz: Verlag für Sammler. Petar ŠIMUNOVIĆ, 1981: Hidronimijski apelativi u hidronimima. Ljubljana.

- -, 1986: Istočnojadranska toponimija. Split: Logos.

Ines VIRČ, 2009: Hidronimija Međimurja. (kvalifikacijski rad u rukopisu)

Ranko ŽUGAJ, 2004: Uvodno o velikim vodama. Velike i male vode, zbornik radova. Zagreb. 1-13. 


\section{JEZIKOVNA SLOJEVITOST IN STRUKTURA MEDŽIMURSKE HIDRONIMIJE}

Prispevek temelji na obravnavi zbranega gradiva medžimurske hidronimije in na analizi onomastične ter druge relevantne literature. Upoštevani so tudi hidronimski podatki, zbrani v pristojnih državnih ustanovah, npr. v Hrvatskih vodah. Zbrano hidronimsko gradivo je klasificirano in analizirano po tvorbeno-motivacijskih kriterijih, pri čemer so ločeni eno-, dvo- in večbesedni hidronimi, za vsako kategorijo pa je dodan tudi grafični prikaz. Glede na to, da je Medžimurje bogato s površinskimi in podzemnimi vodami, so hidronimski podatki, izpisani na podlagi podatkov Hrvatskih voda, zelo bogati, vendar z vidika onomastike manj relevantni od podatkov, pridobljenih s terenskim raziskovanjem. Prispevek je zaključen z analizo jezikovne slojevitosti v zbranem imenskem gradivu in s sklepnimi dognanji, iz katerih je razvidno, da je večina medžimurskih hidronimov motivirana z zemljepisnimi izrazi oziroma z geomorfološkimi značilnostmi samega objekta. 